J. Perinat. Med. 6 (1978) 46

\title{
Blood coagulation and fibrinolysis of the newborn viewed as perinatal factors
}

II. Fibrinolytic studies in the respiratory distress syndrome of the newborn infant*

\section{S. Suzuki}

\section{Introduction}

The Respiratory Distress Syndrome (RDS) has the highest percentage of mortality in the neonatal period of both premature and term infants. On a pathophysiological basis, the disseminated intravascular coagulation syndrome has been recently reported to be a major cause of pulmonary hyaline membrane disease $[1,2,4]$. These findings emphasize the concept of pulmonary hyaline membrane - DIC - predisposition of hemorrhage.

Disseminated intravascular coagulation (DIC) is a pathological condition indicated and characterized by the occurence of intravascular consumption of plasma blood coagulation factors. This applies in particular to fibrinogen, factors II, V and VIII and the number of platelets. This consumption leads to the disseminated deposition of fibrin thrombin in the vascular system and subsequently to severe hemorrhagic diathesis.

The products of DIC have not been fully clarified as yet. There are, however, several conceivable causes for this condition, such as thromboplastin, proteolytic enzyme platelet aggregation, endotoxin etc. Although several possibilities are available to describe the possible relationship between the hyaline membranes and the occurrence of fibrinogen degradation products (FDP), few examinations as yet have been made during the time after birth.

Two typical cases of respiratory distress syndrome with and without bleeding are described in the following:

\footnotetext{
* First part see J. Perinat. Med. 5 (1977) 274
}

\subsection{Case Report}

1.1.1 Case 15, Group (A). $\$ 2400$ gr. Breech presentation. Premature delivery in the 36 th week (Tab. I.). Apgar score 6. At that time the actual $\mathrm{pH}$ value was 7.25 . A catheter was inserted into the umbilical cord vein and bicarbonate therapy was institued. Two hours after birth, the respiration rate increased to $70-80$ per minute. X-ray showed a typical reticular granular pattern. 36 hours after birth the infant died. During the course of events, abovementioned examinations were performed. The change of TEG are shown in Fig. 1. Pulmonary hyaline membranes were discovered at autopsy (Fig. 2).

1.1.2 Case 25, Tab. I, Group (B), $\% 1980 \mathrm{~g}$. She breathed and cried spontaneously. In the premature nursery the

\section{RDS without bleeding}

Cord Blood
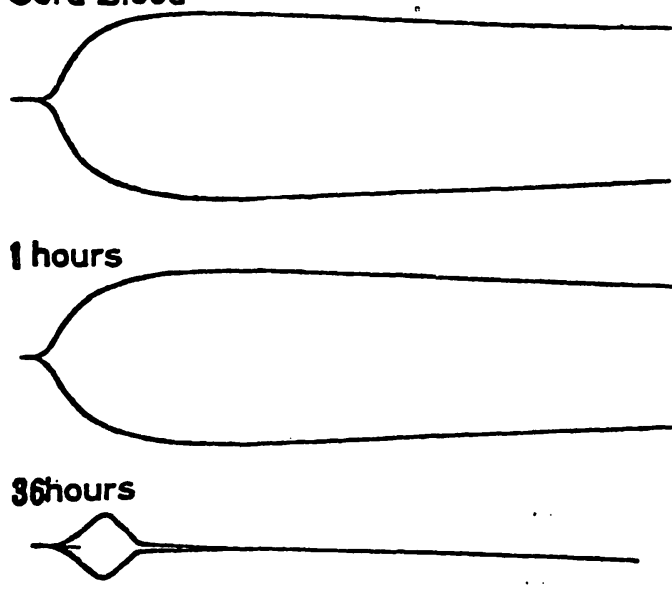

Moribund (intra vascularcoagulation)

.Fig. 1. Case 15: The change of TEG with time. 
Tab. I. Group (A) 22 cases: (NO. 1-22) + sucumbed.

\begin{tabular}{|c|c|c|c|c|c|c|}
\hline NO & $\operatorname{Sex}$ & $\begin{array}{l}\text { Body- } \\
\text { weight }\end{array}$ & $\begin{array}{l}\text { Gestat- } \\
\text { ion W. }\end{array}$ & Apgar & RDS + clin.diag. & $\begin{array}{l}\text { Prognosis } \\
\text { Patholog.diag. }\end{array}$ \\
\hline 1 & $\delta$ & 1500 & 30 & 8 & Hyperbiriluminemia & alive \\
\hline 2 & 9 & 2100 & 36 & 8 & placent.dysfunct. & alive \\
\hline 3 & \& & 2300 & 40 & 5 & placent.dysfunct. & + Hyaline membrane \\
\hline 4 & \& & 2100 & 33 & 8 & Breech presentat. & alive \\
\hline 5 & q & 1850 & 38 & 7 & Hyperbilirubinemia & \\
\hline 6 & \% & 2050 & 33 & 8 & Hyperbilirubinemia & alive \\
\hline 7 & 8 & 2500 & 38 & 6 & Breech Presentat. & alive \\
\hline 8 & o & 2200 & 37 & 5 & Breech presentat. & + H.M.D. \\
\hline 9 & $\delta$ & 2320 & 36 & 7 & Functional ileus. & alive \\
\hline 10 & $\delta$ & 1700 & 34 & 7 & Cord around the neck & + Atelectase \\
\hline 11 & 8 & 2080 & 36 & 7 & Pneumonia? & alive \\
\hline 12 & q & 1900 & 36 & 6 & massive aspiration syndrome & alive \\
\hline 13 & o & 1800 & 34 & 7 & Hyperbilirubinemia & alive \\
\hline 14 & $\delta$ & 2650 & 40 & 6 & Cord around the neck & alive \\
\hline 15 & \% & 2400 & 36 & 6 & Breech presentat. & + H.M.D. \\
\hline 16 & $\delta$ & 1800 & 35 & 8 & placent.dysfunct. & alive \\
\hline 17 & & 2900 & 40 & 5 & Cord around the neck & + H.M.D. \\
\hline 18 & $\delta$ & 1940 & 34 & 6 & & + Atelectasis \\
\hline 19 & $\delta$ & 1580 & 34 & 7 & massive aspiration syndrome & alive \\
\hline 20 & o & 1970 & 34 & 6 & Breech presentat. & alive \\
\hline 21 & o & 2800 & 40 & 10 & Hyperbilirubinemia & alive \\
\hline 22 & \& & 2100 & 37 & 4 & & + Atelectasis \\
\hline
\end{tabular}

Group (B) 26 cases : (NO. 23-48)

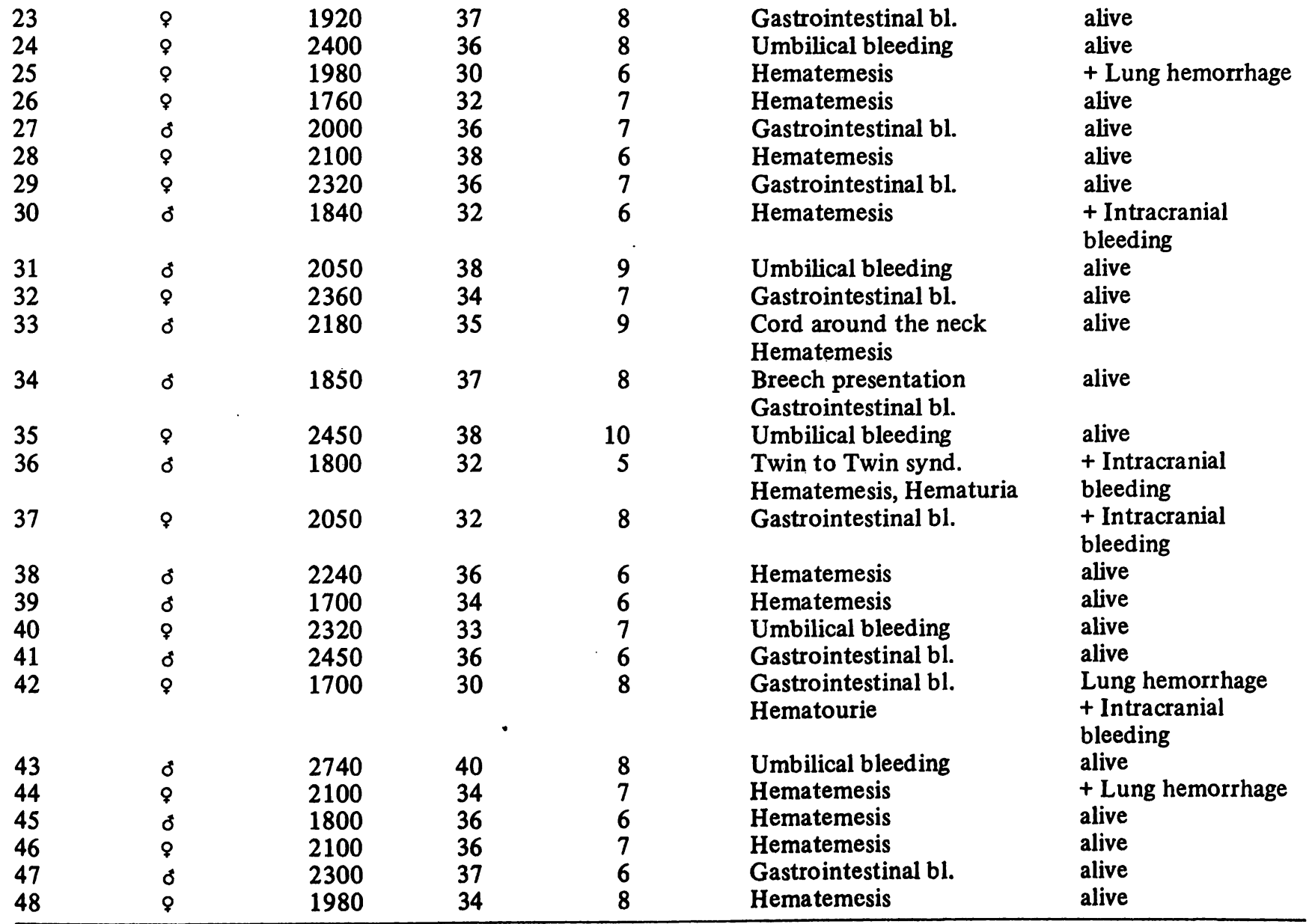




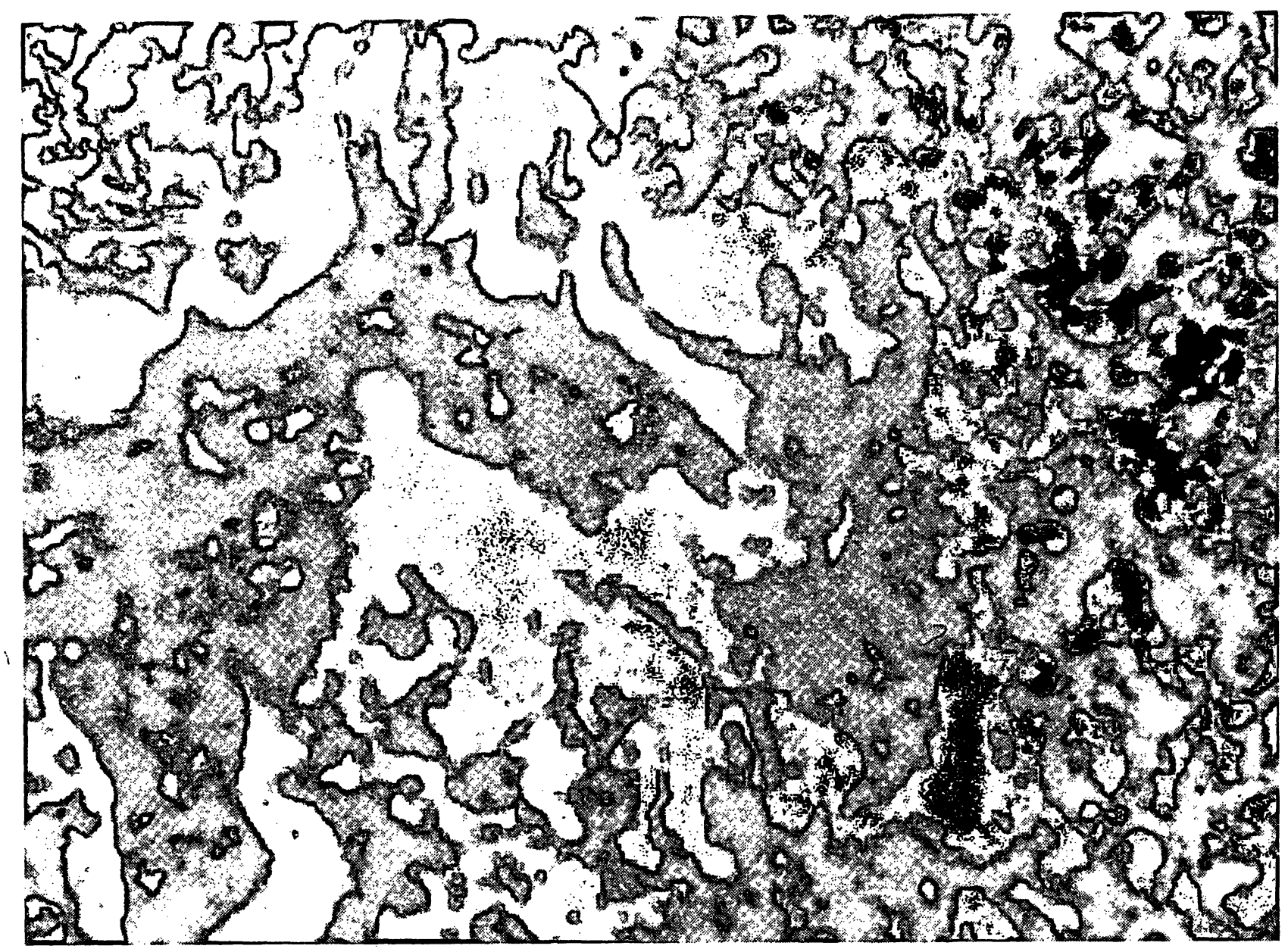

Fig. 2. Case 15: Pathological diagnosis. Hyaline membrane disease (H.M.D.) (400 X HE).

infant did well initially, but after 1 hour the baby developed a slight peripheral cyanosis; 6 hours later bleeding accoured from the mouth. Immediately, $20 \mathrm{ml}$ of fresh blood was given via the umbilical catheter. Apt test were positive leading to the diagnosis of "lung hemorrhage". Although an intensive therapy with "hepacarin" (heparin) was initiated the infant could not be saved (TEG: Fig. 3). Autopsy immediately after death, diffuse bleeding in the lung was observed, although hyaline membrane, intracranial bleeding were missing (Fig. 4).

According to these two cases, the Respiratory Distress Syndrome appears to consist of two different types. One represents a RDS without bleeding, whereas the second type is characterized by the additional occurrence of hemorrhage.

Clinically, symptoms of a Respiratory Distress Syndrome has many features:

1. a respiratory rate over 60 per minute

2. gasping

3. cyanosis

4. dyspnoea.

\section{RDS with bleeding}

\section{Cord Blood}

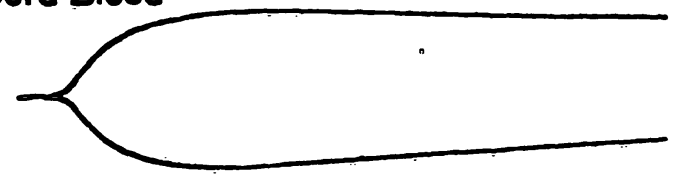

1 hour

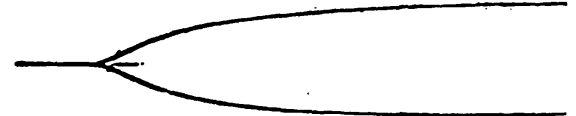

36 hours

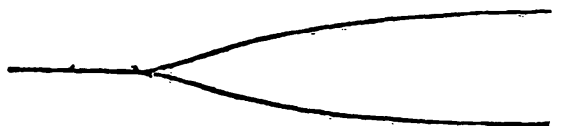

Moribund

Fig. 3. Case 25: The change of TEG with time. 


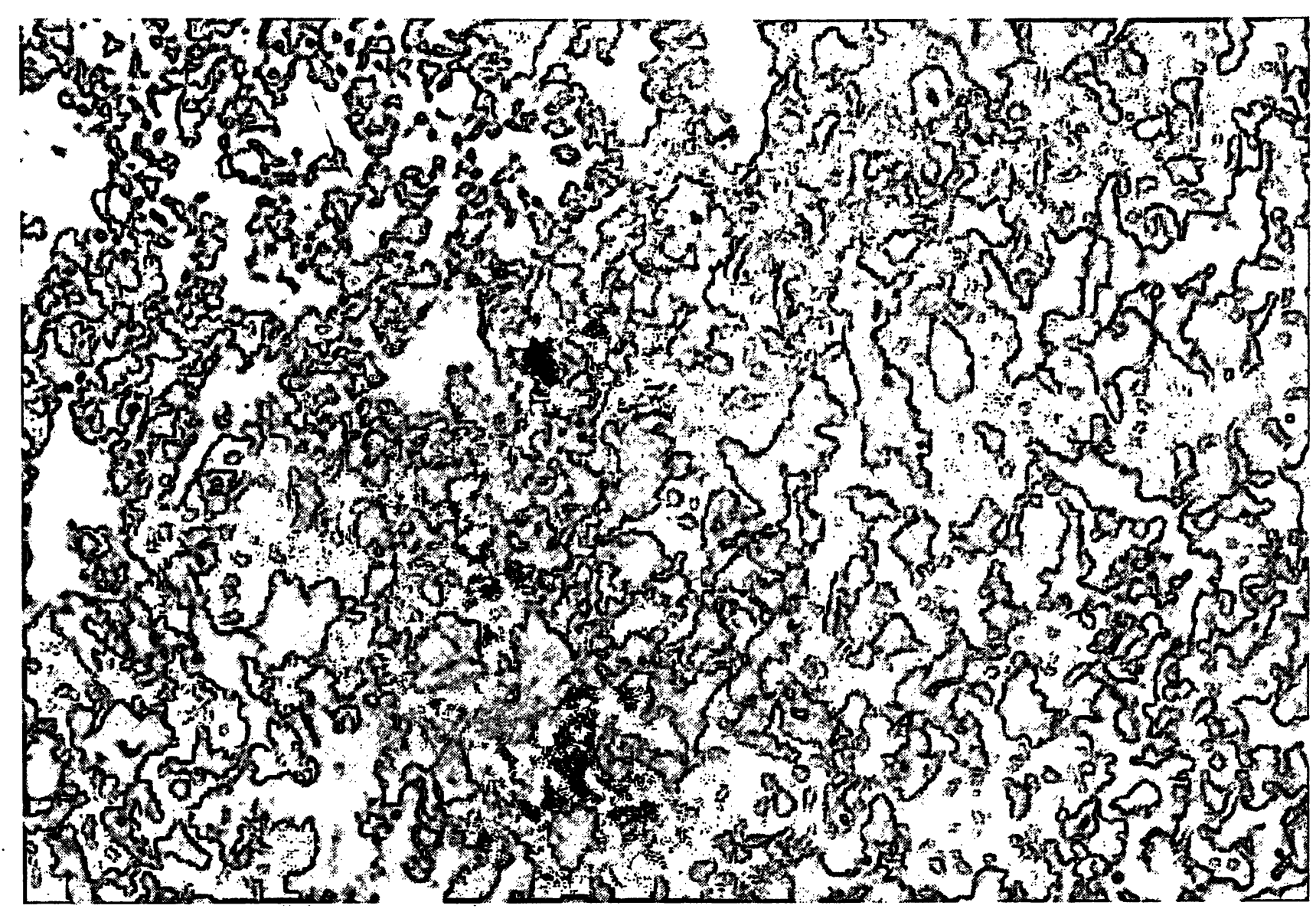

Fig. 4. Case 25: Pathological diagnosis: Lung hemorrhage (400 $\times \mathrm{HE})$.

For this paper, normal infants were compared with infants suffering from RDS with and without bleeding.

\section{Material and methods}

\subsection{Clinical material}

Seventyeight premature and term neonates (1500 g-2900 g) were studied. Group A: 22 cases of RDS without clinical bleeding.

Group B: 26 cases of RDS with clinical bleeding. Group C: 30 cases SFD without complication.

The RDS with clinical bleeding (Group B) were defined as follows:
a) gastroin testinal bleeding
b) hematemesis
c) oozing after injection
d) umbilical bleeding
e) hematuria.

The therapy consisted of intramuscular injection Vitamin $\mathrm{K}_{2}(1 \mathrm{mg})$, sodium bicarbonate and heparin 100-150 units $/ \mathrm{kg}$. The infants who were suffering from RDS received additionally amino-benzylpenicillin $6.25 \mathrm{mg} /$ day. 24 to 36 hours after delivery glucose feedings were offered, whereas no milk was fed during the intravenous infusion.

\subsection{Method of research}

Blood samples were taken as follows.

In RDS cases, the umbilical cord was clamped with $20 \mathrm{~cm}$ spacing after birth and a catheter was used. In normal cases, samples were taken from the femoral arteries.

All blood for the coagulation examinations was obtained with a $2 \mathrm{ml}$ syringe using a 1 part volume of sodium citrate, and a 9 part volume of collected blood. The experiments on all the babies were divided as follows: 


\subsubsection{Blood coagulability}

a) Thrombelastogram

b) Prothrombin time screening for blood coagulation

c) Partial thromboplastin time

\subsubsection{Fibrinoly tic activity}

a) Fibrinogen

b) Euglobulin lysis time

c) FDP

e) Plasmin-inhibitors ( $\alpha_{2}$-macroglobulin, $\alpha_{1}$-antitrypsin, antithrombin III).

\subsubsection{Platelet count and Platelet aggregation}

a) Platelet count

b) Platelet aggregation

Of these items, 2.2.1 a) Thrombelastogram, 2.2.2a) Fibrinogen, 2.2.2b) Euglobulin lysis time, 2.2.2c) FDP have been described previously (part I).

2.2.1 a) Prothrombin time were tested by DADE experiments

2.2.1 c) Partial thromboplastin time

\subsection{2e) Plasmin-inhibitors}

$\left(\alpha_{2}\right.$-macroglobulin, $\alpha_{1}$-antitrypsin, antithrombin III) Plasmin-inhibitors were detected by M-partigen plate (BEHRINGWER KE, Marburg, West-Germany) (Fig. 5).

2.2.3 a) Platelet count (according to REES-ECKER).

2.2.3b) Platelet aggregation.

The citrate blood taken as mentioned above was centrifuged at $1000 \mathrm{rpm}$ for 5 minutes. The blood samples were placed for measurement in a beaker which had been previously warmed to $37^{\circ} \mathrm{C}$.

Platelet aggregation after ADP addition was observed with an automatic recorder (RIKEN, Tokyo, Japan) connected with an aggregationmeter from EvaNs (Great Britain).

ADP solution $10^{-6} \mathrm{M}$ was then added to the beaker and the percent permeability at the time of maximum coagulability as observed within 3 minutes was recorded.

\section{Results}

\subsection{Blood coagulability}

\subsubsection{Thrombelastogram}

As shown in the various cases, the newborn infants who were suffering from RDS with bleeding

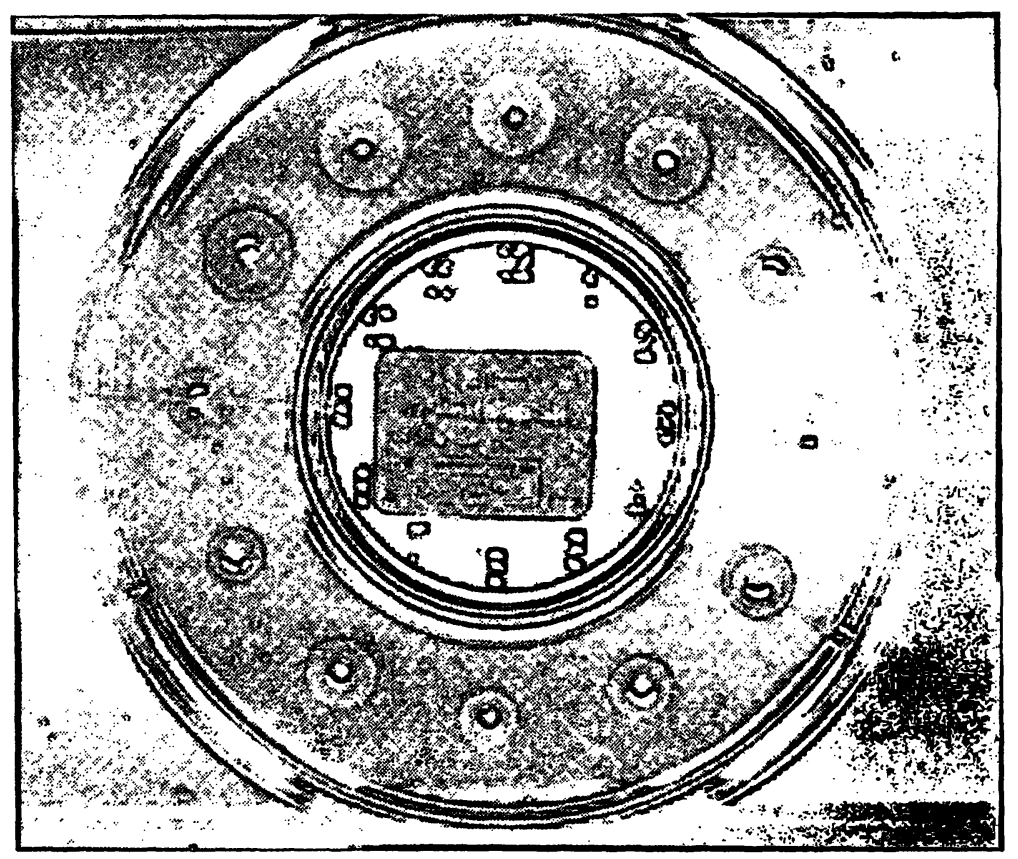

Fig. 5. Detection of plasmin-inhibitors by M-partigen ( $\alpha_{1}$-antitrypsin) (BEHRINGSWERKE, Marburg, West Germany) $M$-partigenplate were also used for the detection of $\alpha_{2}$-macroglobulin and antithrombin III. 
exhibited a pattern different from RDS without bleeding. Noteworthy is the occurrence of hypercoagulability after 1 hour in the cases of RDS without bleeding which lasted longer than usual, and which showed rapid change into a pattern of intravascular coagulation (DIC).

The TEG of RDS without bleeding showed wide ma distances immediately after birth (cord blood $60.34 \pm 1.58$ ), while a value of $51.30 \pm 1.49$ was obtained in the normal group (Tab. II).

The difference was significant at $p<0.01$. After 36 hours, however, the relation of this phenomenon was completely reversed; in other words, infants who had suffered from RDS without bleeding had narrower ma than SFD without complication.

\subsubsection{Prothrombin time, partial thromboplastin time}

All of the infants had a significantly longer prothrombin time and partial thromboplastin time. The values are remarkably low prior to the 2 nd day after birth, but after 3 days a rising tendency was observed (Tab. III). These three examinations in RDS as compared to cases without bleeding the cases with bleeding indicated a greater prolongation of prothrombin time and partial thromboplastin time (Tab. IV).

\subsection{Fibrinolytic activity}

\subsubsection{Fibrinogen and FDP}

With the exception of one case, the continuous fibrinogen decrease was not as pronounced as up to 36 hours after birth, but, in the RDS cases with bleeding, it showed excessive lower levels (Tab. V). The incidence of degradation products in blood from the umbilical cord was $21.8 \%$ (17 cases out of 78 cases). This indicates that fibrinolysis or fibrinogenolysis occurs prior to or at about the time of delivery. The group of lethal RDS with bleeding showed a higher concentration of FDP 1 hour after the delivery which amounts to as much as 80 to $160 \mu \mathrm{g} / \mathrm{ml}$. This tendency did not disappear even after 36 hours. In one case of RDS with bleeding, however, the FDP gradually vanished prior to death with a excessively low fibrinogen level $(50 \mathrm{mg} / \mathrm{dl})$ (Fig. 6).

\subsubsection{Euglobulin lysis time}

Euglobulin lysis time in cases of RDS was shorter than that in SFD without complication. (Fig. 7)

3.2.3 Plasmin-inhibitors ( $\alpha_{2}$-macroglobulin, $\alpha_{1}$ antitrypsin, antithrombin III).

The value of the plasmin-inhibitors ( $\alpha_{2}$-macroglobulin, $\alpha_{1}$-antitrypsin, antithrombin III) during

Tab. II. Change of thrombelastographic ma and $r+k$ (mean \pm S.D).

$m a$

\begin{tabular}{lllll}
\hline $\begin{array}{c}\text { hr } \\
\text { babies }\end{array}$ & Cordblood & $1 \mathrm{hr}$ & $24 \mathrm{hrs}$. & $36 \mathrm{hrs}$. \\
\hline A) RDS without clinical bleeding & $58.45 \pm 2.19$ & $52.88 \pm 2.10$ & $54.43 \pm 1.65$ & $54.15 \pm 1.86$ \\
B) RDS with clinical bleeding & $60.34 \pm 1.58^{*}$ & $53.46 \pm 1.85$ & $44.27 \pm 2.93$ & $41.86 \pm 2.40 *$ \\
C) SFD without complication & $50.45 \pm 1.38$ & $51.38 \pm 2.14$ & $50.56 \pm 1.80$ & $50.48 \pm 1.39$
\end{tabular}

$r+k$

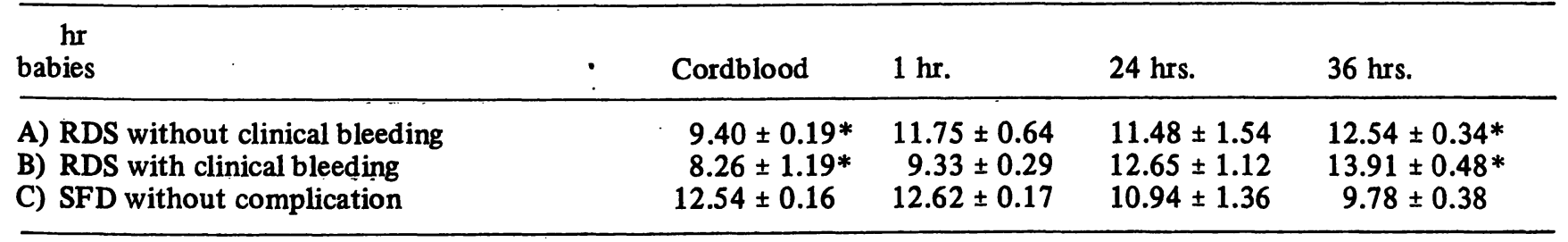

${ }^{*} \mathrm{p}<0.05$ 
Tab. III. Screening test (Prothrombintime, Partialthromboplastintime). (mean \pm S.D).

Prothrombin time (\%)

\begin{tabular}{lllll}
\hline & Cordblood & $1 \mathrm{hr}$. & $24 \mathrm{hrs}$. & $36 \mathrm{hrs}$. \\
\hline A) RDS without bleeding & $35.6 \pm 5.6$ & $32.6 \pm 3.8$ & $35.8 \pm 4.9$ & $34.5 \pm 3.9 *$ \\
B) RDS with bleeding & $34.7 \pm 4.1$ & $28.4 \pm 4.4$ & $24.6 \pm 3.8^{*}$ & $21.1 \pm 5.4^{*}$ \\
C) SFD without complication & $39.0 \pm 3.4$ & $34.3 \pm 4.9$ & $37.3 \pm 5.3$ & $45.7 \pm 4.7$ \\
& & & & \\
Partial thromboplastin time (Sec) & & & & \\
& & & & \\
A) RDS without bleeding & $54.8 \pm 3.8$ & $56.8 \pm 3.6$ & $60.8 \pm 5.6$ & $63.6 \pm 5.4^{*}$ \\
B) RDS with bleeding & $61.3 \pm 4.9$ & $57.5 \pm 5.6$ & $79.8 \pm 7.2 *$ & $84.3 \pm 3.9 *$ \\
C) SFD without complication & $58.4 \pm 6.8$ & $59.4 \pm 4.8$ & $53.6 \pm 2.9$ & $47.8 \pm 5.8$ \\
\hline
\end{tabular}

$*_{\mathrm{p}}<0.05$

Tab. IV. Comparison of coagulation factors between RDS without bleeding and with bleeding (36 hours after birth).

\begin{tabular}{lcc}
\hline $\begin{array}{l}\text { Items } \\
\text { Examination }\end{array}$ & $\begin{array}{l}\text { Respiratory Distress Syndrome } \\
\text { without bleeding }\end{array}$ & with bleeding \\
\hline prothrombin time $<30 \%$ & $63.64 \%(14 / 22)$ & $87.5 \%(21 / 24)$ \\
partial thromboplastin time $>180 \mathrm{sec}$ & $54.5 \%(12 / 22)$ & $81.8 \%(18 / 22)$ \\
Fibrinogen (range) & $210.4(143-279) \mathrm{mg} / \mathrm{ml}$ & $187.6(50-230) \mathrm{mg} / \mathrm{ml}$ \\
& $(210.4 \pm 24.6)$ & $(187.6 \pm 35.6)$ \\
F.D.P. & $80(40-160) \mu \mathrm{g} / \mathrm{ml}$ & $320 \quad(40-640) \mu \mathrm{g} / \mathrm{ml}$ \\
platelet counts (range.) & $17.6(8.7-24.6) \times 10^{4} / \mathrm{mm}^{3}$ & $10.3(5.8-16.9) \times 10^{4} / \mathrm{mm}^{3}$ \\
\hline
\end{tabular}

Tab. V. The change of fibrinogen and FDP during early newbornperiod (mean \pm S.D).

Fibrinogen

\begin{tabular}{lllll}
\hline & Cordblood & $1 \mathrm{hr}$ & $24 \mathrm{hrs}$. & $36 \mathrm{hrs}$. \\
\hline A) RDS without bleeding & $251.8 \pm 33.8$ & $225.4 \pm 23.8$ & $237 \pm 28.4$ & $210 \pm 21.6$ \\
B) RDS with bleeding & $239.6 \pm 27.6$ & $224 \pm 18.7$ & $194.3 \pm 17.6 *$ & $187.6 \pm 24.8^{*}$ \\
C) SFD without complication & $218.6 \pm 21.4$ & $206.8 \pm 18.4$ & $254.6 \pm 20.3$ & $254.5 \pm 28.9$ \\
& & & & \\
F.D.P. The percentage of the cases whose value was over $10 \mu \mathrm{gg} / \mathrm{ml}$ & & & \\
& Cordblood & $1 \mathrm{hr}$. & $24 \mathrm{hrs}$. & $36 \mathrm{hrs}$. \\
\hline & $27.2(6 / 22)$ & $36.3(8 / 22)$ & $80(16 / 20)^{*}$ & $66.7(12 / 18)^{*}$ \\
& $26.9(7 / 26)$ & $50.0(13 / 26)$ & $72(18 / 25)^{*}$ & $85.7(18 / 21)^{*}$ \\
A) RDS without bleeding & $13.3(4 / 30)$ & $30.0(10 / 30)$ & $6.7(2 / 30)$ & $10.0(3 / 30)$ \\
B) RDS with bleeding & & & &
\end{tabular}

${ }^{*} \mathrm{p}<0.05$

the early neonatal period is shown in Fig. 8 and Tab. VI.

No significant difference in $\alpha_{\mathbf{2}}$-macroglobulin was found between SFD without complication and RDS (both with and without bleeding).
The values of $\alpha_{1}$-antitrypsin and antithrombin III did not reach even half of the adult value.

Antithrombin III showed much lower levels in cases of RDS with bleeding than in SFD without complication. 


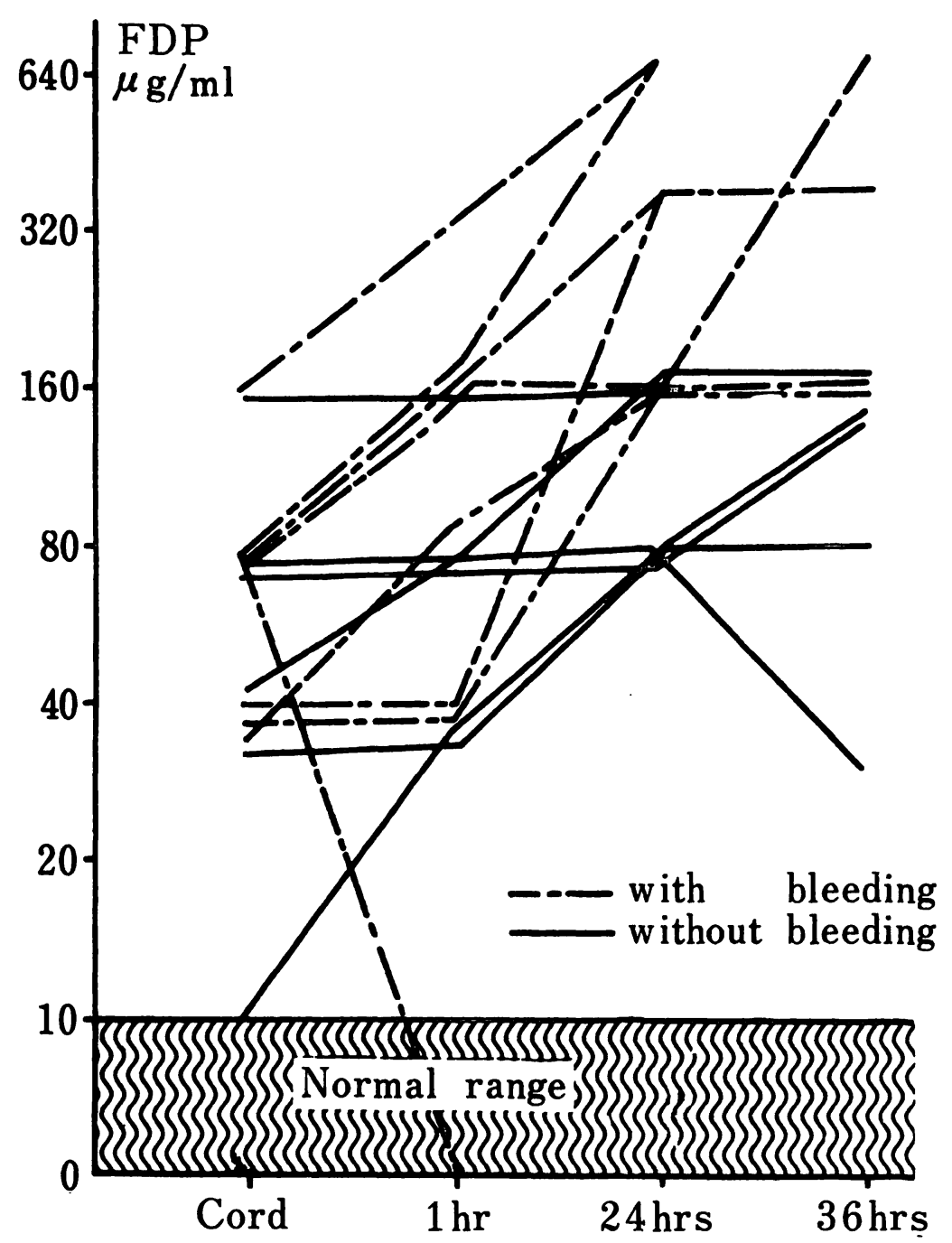

Fig. 6. The change of Fibrin split products (FDP) in the cases of Respiratory Distress Syndrome (RDS). newborn period.

\subsection{Platelet count and platelet aggregation}

The results of platelet count and platelet aggregation are shown in Tab. VII. The average platelet count in 30 babies (Group C) was $18.6 \times 10^{4} / \mathrm{mm}^{3}$. No significant difference was found between Group $A$ (RDS without bleeding) and Group B (RDS with bleeding) After 36 hours, significant differences had developed between Group B (10.3 \pm 3.9$) X$ $10^{4} / \mathrm{mm}^{3}$, and Group C $(21.9 \pm 4.1) \times 10^{4} / \mathrm{mm}^{3}$. $\mathrm{p}<0.01$.

The platelet aggregation index of umbilical cord blood is $15-25 \%$, which is significantly lower than that of normal adults (35-50\%). As mentioned above, the platelet count of umbilical cord blood is $18.6 \times 10^{4} / \mathrm{mm}^{3}$ (average). While these values are not so much lower than those of the normal adults, a tendency to an extremely low platelet aggregation index was found.

\section{Discussion}

The following factors are usually involved in the mechanism of hemostasis:

a) Resistance of the vascular wall and contractibility

b) Property of the platelet (qualitative and quantitative)

c) Property of the coagulation factor

d) Stability of blood clotting, especially fibrinolysis.

Hemostasis takes place as a result of combined action of these factors. Of these, the platelet, coagulation factor and fibrinolysis appear to play 
Tab. VI. The change of Plasmin-Inhibitor during early newborn period (mean \pm S.D).

$\alpha_{2}-$ macroglobulin

\begin{tabular}{lcccc}
\hline & Cordblood & $1 \mathrm{hr}$. & $24 \mathrm{hrs}$. & $36 \mathrm{hrs}$. \\
\hline A) RDS without bleeding & $251.6 \pm 37.6$ & $248.8 \pm 41.4$ & $328.6 \pm 34.6$ & $321.8 \pm 29.5$ \\
B) RDS with bleeding & $248.8 \pm 41.9$ & $260.4 \pm 38.4$ & $317.4 \pm 41.8$ & $315.6 \pm 44.6$ \\
C) SFD without complication & $240.6 \pm 38.2$ & $251.1 \pm 32.6$ & $331.1 \pm 38.6$ & $336.0 \pm 37.8$ \\
& & (Normaladult range 150-420)
\end{tabular}

$\alpha_{1}$-antitrypsin
A) RDS without bleeding
B) RDS with bleeding
C) SFD without complication

\begin{tabular}{|c|c|c|c|}
\hline $\begin{array}{l}100.8 \pm 18.6 \\
101.4 \pm 31.3 \\
105.4 \pm 25.8\end{array}$ & $\begin{array}{r}110.9 \pm 14.6 \\
94.8 \pm 21.5 \\
125.6 \pm 23.6\end{array}$ & $\begin{aligned} 108.6 & \pm 21.6 * \\
96.5 & \pm 19.8^{*} \\
164.8 & \pm 16.6\end{aligned}$ & $\begin{aligned} 99.7 & \pm 16.0 * \\
94.6 & \pm 21.2 * \\
171.4 & \pm 18.4\end{aligned}$ \\
\hline
\end{tabular}

\section{Antithrombin III}
A) RDS without bleeding
B) RDS with bleeding
C) SFD without complication
$11.5 \pm 2.6$
$10.4 \pm 2.8$
$11.8 \pm 1.6$
$8.6 \pm 3.4$
$10.4 \pm 4.6$
$11.6 \pm 3.2$
$12.5 \pm 2.8$
$7.9 \pm 2.5 *$
$15.4 \pm 3.6$

$12.8 \pm 2.4$

$8.2 \pm 3.4 *$

(Normaladulat range 17-30)

$15.6 \pm 4.8$

Tab. VII. The change of Plateletcount and Plateletaggregation-index in early newbornperiod (mean \pm S.D).

platelet count $\times 10^{4} / \mathrm{mm}^{3}$

\begin{tabular}{lllll}
\hline & Cordblood & $1 \mathrm{hr}$. & $24 \mathrm{hrs}$. & $36 \mathrm{hrs}$. \\
\hline A) RDS without bleeding & $17.9 \pm 6.4$ & $19.8 \pm 3.6$ & $20.3 \pm 4.1$ & $17.6 \pm 5.1$ \\
B) RDS with bleeding & $19.4 \pm 8.6$ & $21.6 \pm 4.8$ & $16.8 \pm 4.8 *$ & $10.3 \pm 3.9 *$ \\
C) SFD without complication & $19.6 \pm 4.4$ & $22.1 \pm 4.6$ & $23.3 \pm 3.8$ & $24.9 \pm 4.2$
\end{tabular}

Platelet Aggregationindex (\%)

Cordblood
A) RDS without bleeding
B) RDS with bleeding
C) SFD without complication

$19.2 \pm 4.4$

$18.3 \pm 3.7$

$24.4 \pm 3.3$
24 hrs.

$16.3 \pm 3.8$

$8.7 \pm 4.6 *$

$21.9 \pm 4.0$
${ }^{*} \mathrm{p}<0.05$ an important role as to number and function. On the other hand, neonates with symptoms of RDS can be divided clinically as follows:
a) Pure pulmonary hyaline membrane
b) Hyaline membrane and lung hemorrhage
c) Lung hemorrhage only
d) Atelectasis only
e) Atelectasis plus lung hemorrhage
f) Other

From X-ray or from the clinical course alone, differental diagnosis of these cases is not always easy. Although reports indicating the relationship of pulmonary hyaline membrane cases to fibrinolytic phenomena have been available for a long time, it was not until 1956 that GILTON [5] pointed out that the main component of the hyaline membrane is fibrin. Later, TAYLOR and ABRAMS [21] showed in their in vitro experiments that fibrinogen is inhibited by lipo-protein which is a surface-active substance.

In 1961, LIEBERMAN [15] reported a very low concentration of a plasminogen in the blood of neonates and especially premature babies.

The fibrinolytic activity was demonstrated after placing of lung tissue on a fibrinplate. It was found 


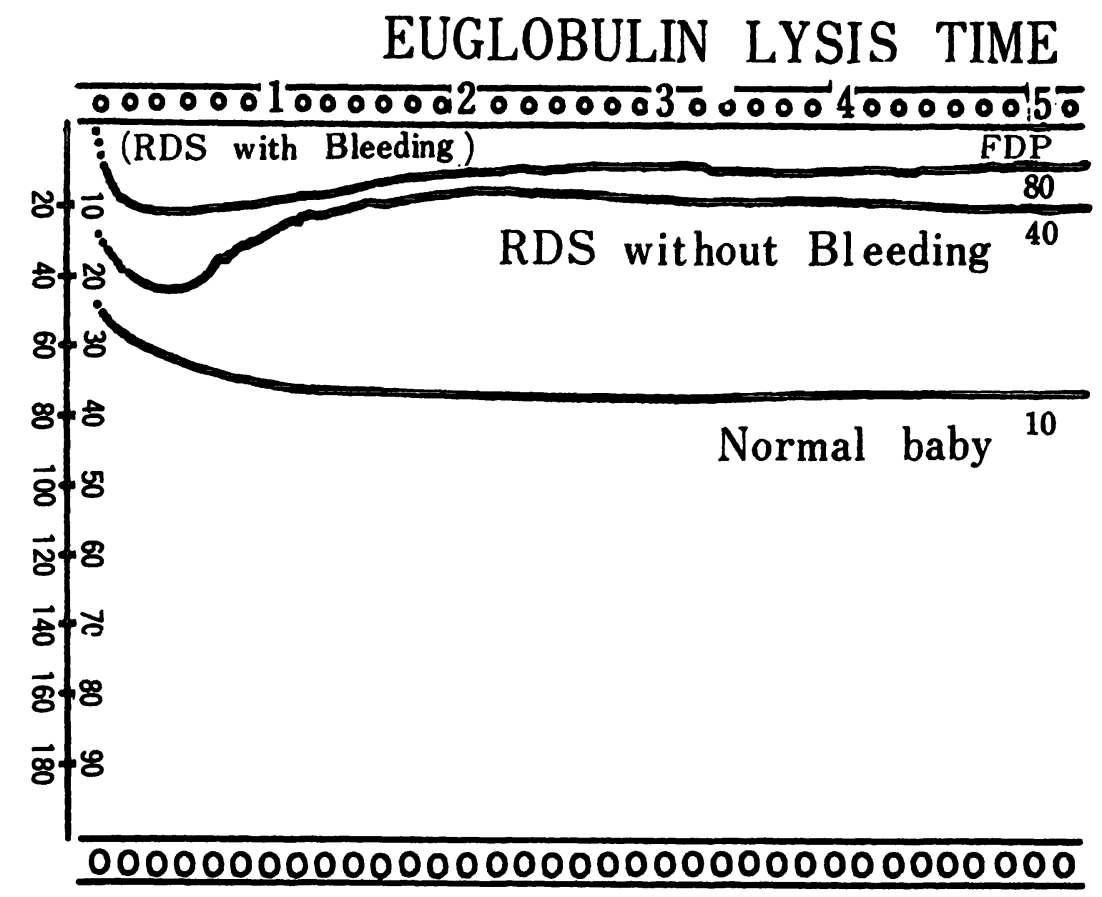

Fig. 7. Euglobulin lysis time (KANAMAN, Great Britain)

(36 hours after birth)
A) RDS without bleeding $128.40 \pm 19.60$
B) RDS with bleeding $88.75 \pm 23.80$
C) Normal babies $238.70 \pm 25.60$
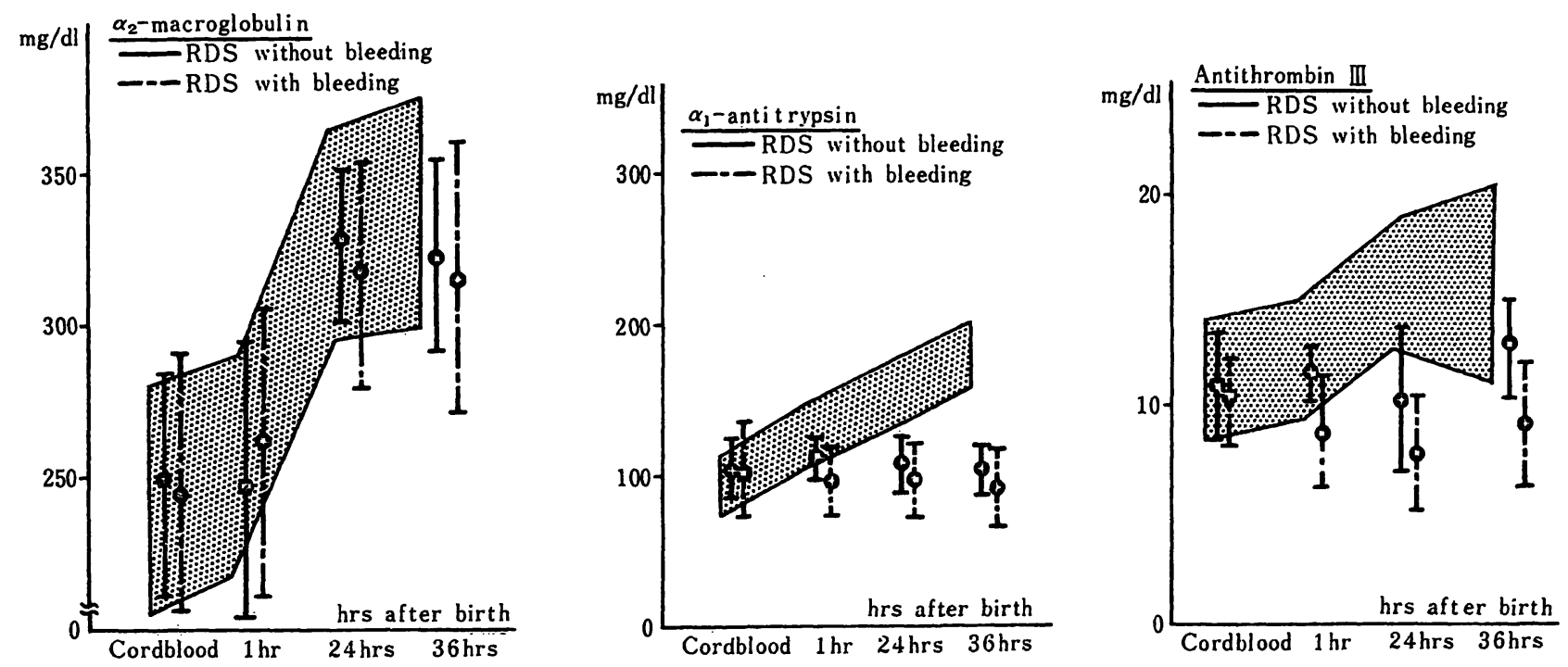

Fig. 8. Levels of different plasmin-inhibitors ( $\alpha_{2}$-macroglobulin, $\alpha_{1}$-antitrypsin and antithrombin III) during early newborn period.

that the presence of plasmin-inhibitor.is the cause of pulmonary hyaline membrane disease rather than the lack of activator. In 1968, BLEYL and STAR K [4] reported in travascular coagulation (DIC) to be an important cause of pulmonary hyaline membrane cases. These authors suspected a process of polymerization of the fibrin monomers seeped into the alveoli, thus leading to the occurrence of hyaline walls.

Fibrin or fibrinogen degradation products (FDP) are a heterogenous group of polypeptides with various molecular weights and different biological 
activities, which may appear in the blood when plasmin acts on fibrin or fibrinogen.

Due to their interference with hemostasis, FDP are extremely important, slowing down the formation of fibrin monomers from fibrinogen either by interference with fibrin polymerization or by their effect on platelet function.

It may be surmised from the present experiments that the consumption of platelet and coagulation factors following disseminated intravascular coagulation results in a fall of the platelet count and fibrinogen. During the newborn period, both the plasmininhibitors, $\alpha_{1}$-antitrypsin and antithrombin III show a remarkable tendency to be low, and it is therefore conceivable that such a decrease may constitute an exceptionally large handicap to the newborn when activation of the plasminogen activator takes place (Group B). This is especially true in cases of lung hemorrhage, where the activator is increased during the development of this severe pathological state and is additionally complicated by the decreased level of plasmin inhibitors. Clinically, the FDP of infants suffering from RDS with bleeding was as high as $80-160 \mu \mathrm{g} / \mathrm{ml}$, and this is higher than that of RDS without bleeding (Fig. 7).

\section{Summary}

Blood coagulation and fibrinolysis was examined in 78 newborns. These comprised (A) 22 infants with hyaline membrane disease without hemorrhage, (B) 26 infants with hyaline membrane disease and clinically apparent hemorrhage, and (C) 30 small for dates infants. The following tests were carried out:

1. General coagulation studies including thrombelastogram (TEG), prothrombin and partial thromboplastin times.

2. Fibrinolytic activity including fibrinogen, euglobulin lysis time, fibrin split products (FDP) and plasmin inhibitors $\left(\alpha_{2}\right.$-macroglobin, $\alpha_{1}$-antitrypsin, antithrombin III).

3. Platelet count and platelet aggregation index after addition of ADP.

Samples were obtained at birth, 1 hour, 24 hours, and 36 hours of age. The results allowed the following conclusions:
This indicates that DIC plays a major role in the hemorrhage of newborn infants with RDS. When compared to the SFD without complication. FDP seemed therefore more frequent and in larger quantities in the RDS babies, and the critical FDP level may be $80-160 \mu \mathrm{g} / \mathrm{ml}$. In one exceptional case of RDS with bleeding the FDP gradually vanished befor death with a lower fibrinogen level $(50 \mathrm{mg} / \mathrm{ml})$. In this latter case, it is difficult to find a satisfactory explanation. It was to be considered that FDP is derived from fibrinogen indicating the shortage of matrix material which would supply FDP. In our clinic it was indeed frequently observed that newborn infants suffering from severe RDS showed lower values of fibrinogen in spite of intensive treatment with fresh blood. These babies seemed to have no ability to react to the fibrinogen in fresh blood. This fact alone cannot give the full explanation, and further evaluation is necessary in this respect.

The platelet aggregation of newborn infants especially those with RDS with bleeding, is very much lower than that of normal adults, while FDP showed great increase. The result can be explained by the possible inhibiting effect of FDP, but it is also difficult to say whether or not FDP has a direct influence on platelet aggregation.

1. Groups A and B were distinctly different from Group C, especially in maximal amplitude (ma) in the TEG. 2. Newborns who died of hyaline membrane disease had markedly elevated FDP values. The critical level appears to be between 80 and $160 \mu \mathrm{g} / \mathrm{ml}$. The plasmin inhibitors $\alpha_{1}$-antitrypsin and antithrombin III were low.

3. The index of platelet aggregation (with ADP) in newborns is lower $(15-25 \%)$ than in adults $(35-50 \%)$. Newborns with hyaline membrane disease had a decreased platelet count and platelet aggregation index while the amount of fibrin split products was increased.

Thus, it may be stated that the coagulation defect in infants with hyaline membrane disease is not only dependent on Vitamin $\mathrm{K}$ deficiency but also expresses an on-going consumption coagulopathy.

Keywords: Blood coagulability, fibrinolysis, hyaline membrane disease. 


\section{Zusammenfassung}

Blutgerinnung und Fibrinolyse beim Neugeborenen.

II. Fibrinolyse beim Membransyndrom des Neugeborenen. Es wurden insgesamt 78 Neugeborene bezüglich ihrer Blutgerinnung- und Fibrinolysefähigkeit untersucht. Davon zeigten (A) 22 Fälle ein Membransyndrom ohne klinische Blutung, (B) 26 Fälle ein Membransyndrom mit klinischer Blutung und (C) 30 Fälle waren paedatrophische Kinder.

Unsere Untersuchungen lassen sich in drei Teile gliedern:

1. Allgemeine Blutgerinnungsuntersuchungen, wie TEG, Prothrombinzeit und partielle Thromboplastinzeit.

2. Fibrinolytische Aktivität: sie wurde beurteilt nach dem Fibrinogen, der Euglobulinlysezeit, dem auftretenden FDP und den Plasmin-Inhibitoren ( $\alpha_{2}$-Makroblobulin, $\alpha_{1}$-Antitrypsin, Antithrombin III).

3. Thrombozytenzahl und Thrombozytenaggregationsfähigkeit mit Zusatz von ADP.

Diese Untersuchungen wurden zum Zeitpunkt der Geburt sowie 1 Std., 24 Std. und 36 Std. postpartum durchgeführt.
Aus den Ergebnissen dieser Untersuchungen können folgende Schlüsse gezogen werden.

1. Gruppe (A) und (B) unterscheiden sich deutlich von Gruppe (C), vor allem in der maximalen amplitude (ma).

2. Bei den Neugeborenen, die an einem Membransyndrom verstarben, war der FDP-Wert selbst in hoher Verdünnung noch nachweisbar. Der kritische Grenzwert scheint zwischen $80 \mu \mathrm{g} / \mathrm{ml}$ und $160 \mu \mathrm{g} / \mathrm{ml}$ zu liegen. Der PlasminInhibitoren, $\alpha_{1}$-antitrypsin und Antithrombin III zeigten niedrige Werte.

3. Der Thrombozy tenaggregationsindex (mit ADP) beim Neugeborenen ist niedriger $(15-25 \%)$ als beim Erwachsenen (35-50\%). Beim Membransyndrom zeigten die Neugeborenen einen Abfall der Thrombozytenzahl genauso wie der Thrombozytenaggregationsindex, während die Konzentration der Fibrinspaltprodukte (FDP) anstieg.

Es läßt sich also feststellen, daß der Mangel an Blutgerinnungsfähigkeit bei den Fällen mit Membransyndrom nicht nur vom Vitamin-K-Mangel abhängt, sondern auch von einer bestehenden Verbrauchskoagulopathie.

Schlüsselworte: Blutgerinnungsfähigkeit, Fibrinoly sefähigkeit, Membransyndrom.

\section{Résumé:}

Coagulation sanguine et fibrinolyse du nouveau-né Facteurs pèrinataux

II. Etudes de la fibrinolyse dans la dyspnée des nouveauxnés

Nous avons examiné les facteurs de coagulation et de fibrinolyse chez 78 nouveau-nés. Nous avons observé dans 22 cas (A) un syndrome membraneux sans hémorragie clinique, dans 26 cas (B) un syndrome membraneux avec hémorragie clinique et dans 30 cas (C) des enfants pédatrophiques.

Nos examens peuvent se diviser en trois parties:

1. Examens généraux de coagulation sanguine (TEG, estimation de prothrombine et de thromboplastine partielle).

2. Activité fibrinolytique, déterminée par le fibrinogène, le temps d'euglobulinelyse, le FDP apparent et les inhibiteurs de plasmine ( $\alpha_{2}$-macroglobuline, $\alpha_{1}$-antitrypsine, antithrombine III).

3. Taux de thrombocytes et facteur de thrombagrégation avec addition d'ADP.

Ces examens ont été effectués au moment de l'accouch- ement ainsi qu'1 h., 24 h. et 36 h. post partum. Les résultats peuvent donner les conclusions suivantes:

1. Les groupes $\mathbf{A}$ et $\mathbf{B}$ se différencient nettement du groupe C, surtout par l'amplitude maximale (ma).

2. Chez les nouveaux-nés qui sont morts par suite d'un syndrome membraneux, la valeur de FDP a pu être déterminée même sous forte atténuation. Il semble que la valeur-limite critique se situe entre $80 \mu \mathrm{g} / \mathrm{ml}$ et $160 \mu \mathrm{g} / \mathrm{ml}$. Des valeurs basses ont pu être relevées pour les inhibiteurs de plasmine, $\alpha_{2}$-antitrypsine et antithrombine III.

3. L'index de thrombagrégation (avec ADP) chez le nouveau-né est plus bas $(15-25 \%)$ que chez l'adulte (35-50\%). Dans les cas de syndrome membraneux, les nouveaux-nés ont manifesté une baisse du fany de thrombocy tes comme pour l'index de thrombagrégation, tandis que la concentration des produits de fission de fibrine (FDP) avait augmenté.

De ceci il résulte qu'une défection dans la coagulation sanguine dans les cas de syndrome membraneux dépend non seulement d'une carence de vitamine $K$, mais aussi de la présence de coagulopathie de consommation.

Mots-clés: Facteur de coagulation sanguine, facteur de fibrinolyse, syndrome membraneux.

Acknowledgement: The helpful advices of Prof. Dr. H. Ludwig (Essen), Prof. Dr. H. Haupt (Duisburg) and Prof. Dr. H. Graeff (München) are gratefully acknowledged.

These research were supported by Alexander von Humboldt foundation in Bonn-Bad Godesberg. 


\section{Bibliography}

[1] AMBRUS, C. M., D. H. WEINTRAUB, D. DUNPHY, J. E. DOWD, J. W. PICKREN, K. R. NISWANDER, J. L. AMBRUS: Studies on hyaline membrane disease. I. The fibrinolysin system in pathogenesis and therapy. Pedatrics 32 (1963) 10

[2] AMBRUS, C. M., D. H. WEINT RAUB, K. R. NISWANDER, J. L. AMBRUS: Studies on hyaline membrane disease. II. The ontogeny of fibrinolysin system. Pediatrics 35 (1965) 91

[3] BELLER, F. K.: Die Gerinnungsverhältnisse bei der Schwangeren und beim Neugeborenen. Barth, Leipzig 1957

[4] BLEYL, U.: Schock disseminierte intravasale Gerinnung und idiopathisches Atemnotsyndrom der Neugeborenen. XIII International Congress of Pediatrics, Wien. Haematol. (1971) 11

[5] GILTON, D., J. M. CRAIG: Nature of the hyaline membrane in asphyxia of the newborn. Pediatrics 17 (1956) 64

[6] GRAEFF, H., R.VON HUGO, W. KUHN, H. SCHOLZ, A. ERNST, R. GASTROPH: Fibrinogen derivatives with a higher molecular weight than that of the parent molecule in cord vein plasma of newborns. I. Identification in single plasma samples. Klin. Wschr. 51 (1973) 695

[7] HAUPT, H.: Pathogenese des hämorrhagischen Syndroms Neugeborener. Med. Klin. 67 (1972) 245

[8] HAUPT, H.: Einwirkung pränataler Hypoxie auf das Gerinnungssystem des Neugeborenen. Z. Kinderheilk. 113 (1972) 183

[9] HAUPT, H.: Die Blutgerinnung beim Neugeborenen (Physiologie, Pathologie und Therapie) Mschr. Kinderheilk. 104 (1956) 1

[10] IWASAKI, R.: Studies on fibrinogen in the newborn period. Japan. J. Neonat. Med. 9 (1973) 58

[11] IWASAKI, R.: Studies on Fibrin splits product in the newborn period. Japan. J. Neonat. Med. 9 (1973) 65

[12] IWASAKI, R.: Fibrinolysis in Caesarian section. XIth Congress of the japanese society on plasmininvestigation. Sapporo 1972
[13] KOMINAMI, Y.: Crush syindrome. Japan. J. Neonat. Med. 9 (1973) 1

[14] LAURITZEN, CHR.: Oestrogene in Theorie und Praxis. Klinge, München 1974

[15] LIEBERMAN, J.: The nature of the fibrinolytic enzyme defect in hyaline membrane disease. New Engl. J. Med. 265 (1961) 363

[16] LUDWIG, H.: Mikrozirkulationsstörungen und Diapedeseblutungen im fetalen Gehirn bei Hypoxie. Karger, Basel 1968

[17] MURAKAMI, G.: The new method of laboratory test in Fibrinolysis. Japan. J. Clin. Pathol. 13 (1965) 10

[18] RATNOFF, O. D., C. MENZIE: A new method for the determination of fibrinogen in small samples of plasma. J. Lab. Clin. Med. 37 (1951) 316

[19] SHIRAHATA, S.: The change of Blood Coagulation and Fibrinolysis in Respiratory distress syndrome. Japan. J. Neonat. Med. 10 (1974) 11

[20] SUZUKI, S.: Consumption coagulopathy in the obstetric field. J. Japan. Clin. 32 (1974) 1077

[21] TAYLOR, F., M. B. ABRAMS: Effect of surface active lipoprotein on clotting and fibrinolysis and of fibrinogen surface active lipoprotein. With a hypothesis on the pathogenesis of pulmonary athelectasis and hyaline membrane in respiratory distress syndrome of the newborn. Amer. J. Med. 40 (1966) 346

[22] YAMADA, K.: The study of splits product of fibrin in the newborn infants. J. Japan. Haematol. 35 (1972) 646

[23] YAMANAKA, J.: Fibrinolysis in the newborn immediately after birth. Japan. J. Neonat. Med. 7 (1971) 189

[24] YAMANAKA, J.: The daily variation of the fibrinolysis in the newborn period. Japan. J. Neonat. Med. 7 (1971) 199

[25] YAMANAKA, J.: Fibrinolytic study of the newborn so-called "Characteristic of Caesarian section syndrome'. Japan. J. Neonat. Med. 7 (1971) 211

Received July 4, 1976. Accepted August 29, 1977.

Dr. Shigenori Suzuki

Department of Obstetrics \& Gynecology Hokkaido University of Medisin (Hokudai Byoin)

Kita 14-jo, Nishị 5-chome, Kita-Ku Sapporo 060 Japan 